\title{
Economic Approaches of Zakat Management Institutions in Malaysia
}

\author{
Zakaria Bahari $^{1}$, Caturida Meiwanto Doktoralina ${ }^{2}$ \\ \{bzak@usm.my ${ }^{1}$, caturida_meiwanto_drm@mercubuana.ac.id $\left.{ }^{2}\right\}$ \\ ${ }^{1}$ Center for Islamic Development Management Studies, Universiti Sains Malaysia, Malaysia \\ ${ }^{2}$ Fakultas Ekonomi dan Bisnis Universitas Mercu Buana, Jakarta, Indonesia
}

\begin{abstract}
This paper aims to identify the types of economic approaches, philosophies and economic theories used in the implementation of productive zakat in zakat institution in Malaysia. This study is a qualitative study using informantion from the field through zakat practitioners as well as secondary data from journal materials, reports, websites and books. This study used conventional content analysis to analyse data. The findings show that the form of economic approach applied is self-serving, collaborates between zakat institutions and smart cooperation approaches wit external agencies. The philosophy of economics is to use fishing rod and not the fish, an no economic theory is applied. Zakat institutions provide the programs through capital assistance, courses, training skills and equipment assistance.
\end{abstract}

Keywords: Zakat Distribution; Productive Zakat; and Economic Approaches.

\section{Introduction}

The productive zakat distribution has become one of the agenda in zakat institution by both government and non-government in order to eradicate the poor and needy beneficiaries of zakat (asnaf) from being a zakat recipient. Most activities undertaken by the institution are to develop human resources such as human development programs and particularly their economy through economic development programs and entrepreneurs [1]. Among the economic development programs carried out by the institution are in the form of human capital, financial aid and capital goods consisting of equipment, machinery, technology, sites and building business space by rent. Also, assistance and programs involving short-term courses, training and skills as well as mentoring are committed to enhance asnaf skills and productivity [2,3] The implementation of the productive zakat is carried out by the Entrepreneur Development and Economic Development divisions at the zakat institution according to their respective methods. This is due to the fact that the zakat institutions has its own management and administration because of its authority by state based on the enactment of different States by law, especially concerning Malay Religion and Customs directly under the Sultan or King. The power of the Sultan is to be the head of state for the Sultanate and the Kingdom and the supreme Sultan or Yang Dipertuan Agong for the states without Sultan or King. For Zakat management and administration, its sole trustee is under the respective State Islamic Religious Council (MAIN). However, generally in terms of implementation of zakat management, it can be divided into 3 zakat model offices, which are fully managed by the State Islamic Religious Council (Johor, Kelantan, Perak, Perlis and Terengganu), collection office corporation (Federal Territory, Malacca, Negeri Sembilan and Pahang) and 
corporations (dedicated to collecting and distributing zakat) and owned by MAIN (Selangor, Penang, Sabah, Sarawak and Kedah) [4].

Productive Zakat is distributed with the purpose of fishing, rather than giving fish to increase productivity and income to escape from becoming the group and become a muzakki instead. The differences in the structure of the zakat institution in the states of Malaysia will certainly bring about differences in the nature of zakat distribution in general and in particular the productive distribution of zakat. These differences will inevitably lead to different types of economic approaches in the zakat institution as well as the management and Standard Operating Procedure (SOP). The specialized distribution of zakat uses several economic approaches to distribute the zakat to eligible beneficiaries. The question is, what kind of economic approach is used by the zakat institutions to increase their productivity and hence their income? What are the economic philosophies and theories that are applied in the implementation of these economic approaches? How these economic approaches are implemented in these zakat institutions? Therefore, this paper aims to: first, identify the types of economic approaches given to asnaf in selected zakat institutions in Malaysia. Second, identify the philosophies and theories used in implementing these economic approaches. Third, how these economic approaches are implemented in zakat institutions?

The discussion of the sub-topics in this paper begins with an introduction, followed by literature reviews, methodology, discussion and finally a conclusion.

\section{Literature Review}

The efforts to develop entrepreneurship and economic growth are essential for achieving the Maqasid Shariah in the implementation of zakat [5,6]. [7] conducted a study on economic and entrepreneurial assistance to poor and needy asnaf to increase their income at the Lembaga Zakat Selangor (LSZ). Among the assistance provided are courses, training and skills, capital assistance and many other facilities such as business site, shop buildings, machinery and equipment. Subsequently, [3] conducted a study of LSZ and its organized and consistent Zakat capital assistance on the poor and needy asnaf increase their income. This assistance program has been implemented in the form of educational, economic, human development and religious institutions such as religious schools, mosques and traditional schools.

[2] conducted a study on the implementation of productive zakat conducted at the Zakat Management Center (now converted to Zakat Penang) in an effort to increase the income of the group and hopefully escape the group. Among the help are through asnaf A score movement, asnaf tailoring movement, asnaf plantation movements, asnaf handicrafts and agro-business movements involving capital assistance, equipment, business sites, marketing, courses, training and skills. There are weaknesses among the asnaf which include lack of skills, lack of production factors and lack of knowledge. [6] conducted a study at the LSZ and the Federal Territory Islamic Religious Council, Kuala Lumpur (MAIWP). LSZ provides assistance to entrepreneurs in zakat involving business capital (RM 5 million), fishery capital assistance (RM0.4 million) and fishery capital (RM0.2 million) involving 959 asnaf. MAIWP also assisted with its own taxi which deposited through an allocation of RM3.02 million, agricultural assistance of RM23,750.00 to boost its revenue in 2012. [8] conducted a study on the problems and effectiveness of asnaf entrepreneurs' development program. He noted that talent, motivation and self-confidence were still lacking, lack of human resources in zakat institutions, lack of expertise and monitoring were the problems of the economic assistance program. 
[9] has researched productive zakat aid in Aceh, Indonesia through Qardhu Hassan financing with revolving funds tailored to local wisdom. Assistance is provided through the agriculture, trade, fishing, and household industries through screening, assistance and monitoring are provided. This grant is like micro-credit financing [10].

The success of these entrepreneurs plays a social role in helping those in need to improve their economic situation while also becoming a muzakki [5]. Efforts to develop the asnaf economy have not only been initiated by zakat institutions but also have been successful as icons to inspire and guide the beneficiaries.

In addition, [11] has suggested that besides providing capital assistance, training, courses and skills, zakat institutions can also provide micro-credit loans to asnaf, for institutions to build zakat academy to provide courses, training and skills to asnaf, projects groups such as the Amanah Ikhtiar Malaysia Project (AIM) model, and the Group Agriculture Project.

From all the previous studies discussed above, it is shown that in the distribution of productive zakat, zakat institutions have provided various programs such as training, courses, skills, capital assistance, equipment, sites and places of business, mentoring to the poor and needy asnaf. The purpose of the aid is for asnaf to be more productive in order to increase their income so that in time it will escape the poor and even become a muzakki. In addition, there are zakat institutions that have implemented micro-credit financing to facilitate traders and entrepreneurs to acquire qardhu Hassan capital such as in Aceh, Indonesia. However, it is not uncommon for early researchers to study the productive zakat in the form of its economic approach, both in terms of its philosophy and economic theory. Also, research that examines the entire MAIN in implementing a program and productive zakat distribution is extremely rare. Therefore, this study seeks to cover the gaps of the empirical study by examining the implementation of programs and aids in the productive zakat in MAIN Malaysia as well as the philosophy and economic theory used in its implementation.

\section{Methodology}

This study is a qualitative study involving primary and secondary data collection. Primary data is obtained through in-depth interviews with zakat management practitioners at the centers of zakat institutions, particularly those involved in economic development and asnaf entrepreneurs. Secondary data were obtained based on previous research such as theses, books, articles, journals, magazines, annual reports and websites. This data was then analyzed by qualitative content analysis to achieve the objectives of this paper.

\section{Discussion}

As a result of in-depth interviews with informants consist of zakat practitioners; it appears that zakat centers in Malaysia do not clearly explain the nature of their economic approach. This means that no terms or names of economic approaches implemented in various economic programs to develop asnaf that have been carried out. Based on in-depth interviews, researchers can conclude that there are three types of economic approaches that have been implemented. The forms of economic approaches are individual economic approaches, collaborative approaches among zakat centers, and collaborative approaches with agencies outside the zakat institution.

In these unique economic approaches, the zakat centers in Malaysia carry out their own economic activities, without any contact with the other parties. Much of these economic activities are focused on self-help, short-term courses such as the selection of participants 
expected to receive assistance, baking, sewing, equipment such as sewing machines, boats and engines, capital round, shops and business sites. Short-term courses and training are provided by recruiting beneficiaries who have been successfully exempted as trainees, motivators and mentors, as conducted by the Johor State Islamic Religious Council (MAINJ), Penang Zakat (ZPP) and Sabah Zakat Center at the Sabah Islamic Religious Council (PZS-MUIS).

The second economic approach is through cooperation with state zakat institutions such as the 2012 project at Asnaf Batu Berangkuk Village, Chuping in Perlis between the LZS and the Perlis Islamic Religious and Malay Customs Council (MAIPs) in developing the asnaf economy in chili production. The project provides accommodation, with agricultural use of modern technology (such as rockmelon plantation, downstream and freshwater fish farming (tilapia) involving 50 poor and needy asnaf households. Participants are given a monthly salary of RM1,000.00 and they are advised to make savings of RM300.00 per month and stay in the space provided for 5 years. This project will be supervised by a supervisor appointed by the management of the zakat institution, which not only develops economic potential but also provides spiritual and religious guidance. Examples include asnaf placements in collaboration with LZS and Kelantan Islamic Religious Council (MAIK) in Shah Alam Village, Pasir Putih, Kelantan in economic projects, Terengganu Islamic Council and Malay Customs (MAIDAM) in Kampung Banggol, Kuala Terengganu, Terengganu and Pahang Islamic Religious and Malay Customs Council (MUIP) in Bukit Kenau, Pahang are also involved in economic development. This cooperation also involves the efforts of zakat institutions in sowing and strengthening the spiritual aspects of asnaf.

The last economic approach is the co-operation of state charity institutions in Malaysia with external agencies, whether in cooperation with departments or government agencies and private agencies. Training, courses and skills assistance from government agencies and departments are the Ministry of Women, Family and Community Development, Ministry of Rural Development (KEMAS), People's Trust Council (MARA), Standard and Industrial Research Institute of Malaysia (SIRIM), Malaysian Agricultural Research and Development Institute (MARDI), Economic Planning Unit (UPEN), Islamic Dakwah Foundation of Malaysia (YADIM), Federal Agriculture Marketing Authority (FAMA), Malaysia External Trade Development Corporation (MATRADE), Construction Industry Development Board (CIDB), Terengganu Skills Development Centre (TESDEC), Ria Academy College and higher education institution (Universiti Utara Malaysia - UUM), Sultan Abdul Halim Shah International Islamic University (UniSHAMS) and University of Technology MARA UiTM), Kedah Industrial Skills and Management Development Centre (KISMEC).

The economic approaches to cooperation with the private sector include TERAJU Sdn Bhd (LZS) and Naza Academy (automotive courses); Construction Academy of Malaysia (ABM) for heavy machinery and the Construction Industry Development Board (CIDB) (plastering course). The implementation of this agreement not only began with the training of the participants but also employed the participants. Similarly, the skills/training program conducted under the management of the Islamic Religious Council Perak (MAIPk) with ABM; SekataRakyat and United Engineering Malaysia (UEM) Bhd Group: and Kedah Zakat Board (LZNK) with ABM and CIDB.

Economic and entrepreneurial activities in these approaches are mainly focused on skills training for asnaf, and mostly for their children. These external agencies not only train participants with skills but also secure them with jobs upon completion of the training. Among the skills provided are automotive skills, welding, air conditioning, scanning, construction, blasting and painting, back hole loader, solar, cooking, sewing, and more. 
Almost all zakat institutions in Malaysia prefer to collaborate with these external agencies rather than setting up and operating their own training centers. The reasons are, first of all, these agencies have in-depth skills in the fields offered which are highly demanded and fullyequipped because the human resource of the zakat institution lacks the skills offered and also the equipment to be used in training. Second, the cost of collaboration is relatively lower than if the zakat institutions set up and operate their own skills training centers that involve location, skills and motivation.

Explaining the interview information, it is possible to conclude that all the zakat institution practitioners stated that they have no economic background in implementing a productive zakat program involving entrepreneurship and economic development. They do not have the standard or written economic philosophy and conduct them following the appropriateness and practicality that they think is right. Usually, they would refer to the implementation of aids, economic programs and entrepreneurship by other zakat institutions. Similarly, from the economic point of view, it is found that practitioners of zakat institutions in Malaysia as a whole do not follow any theory, either conventional economic theory or Islamic economy. All they are doing is implementing economic assistance and programs through an economic approach that they think is good and realistic based on their experience. In addition, they applied the economic assistance and entrepreneurship programs conducted by other zakat institutions.

The early philosophy practiced by the zakat institution in Malaysia almost all adhered to the philosophy of "giving a fishing rod" instead of giving the fishes to the poor and needy asnaf, the mualaf and those fisabiliillah who needed help and economic programs to supplement their income. "Giving a fishing rod" here means to provide equipment and capital or cash assistance as a start-up or fundraising venture. Zakat institutions move further by providing training or courses to learn how to use and handle the rods more effectively. This is due to the fact that the rods provided are found to be unknown to the most asnaf and they do not know how to handle it. The final step is to determine where the strategic location to use the rod; in fishing, the place with most fishes.

The chronology begins by assuming it is based more on the evolution of the trial and error experience in implementing the aids, economic programs and entrepreneurship of the zakat institution, rather than on any specific philosophy and economic theory. The beginning stages are often provided with financial and equipment assistance. Financial aid and equipment provided are not productive and can increase income, zakat institutions then provide courses, training and skills to the students so that they can use the equipment provided properly (for example by providing cooking courses, weaving skills, sewing, training in handling production and stock as well as acceptable skills in working areas). Eventually, the zakat center has developed a strategy for marketing to sell asnaf products by providing a site or place of business and entrepreneurs that would easily sell asnaf products and services. In addition, skills training also provided employment opportunities. Therefore, many zakat institutions have partnered with external parties to provide skills training and eventually job training. In other words, the philosophy of the economic approaches of the zakat management centers in Malaysia evolved based on the experience of these zakat institutions in helping the ex-beneficiaries. Some of these efforts have been successful completed by some zakat institutions, but some have not been fully successful.

In the economic approach, none of the zakat institutions in Malaysia have any economic theory or based their approach on any economic theory, either conventional economic theory or Islamic economic theory. They are simply implementing an economic approach based on 
what they think is good, or based on their own experience, or following the economic programs at successful zakat institutions.

The economic approach taken is not based on economic theory in general. This is because zakat institution officials in Malaysia are less likely to read theoretical subjects, let alone keep pace with the development of well-organized and integrated research on zakat-related academic publications. If any reading is made, it is based solely on the personal interests of the officers, or based on their work relationship, or simply for the sake of attending conferences, seminars or courses. This has led to the fact that zakat institutions in Malaysia do not have any economic theory or basis for any economic theory in implementing aids and programs of economic development and entrepreneurship. The practice of zakat institutions is to implement economic development as it refers to what they feel is appropriate under the current circumstances, or based on the experience of their own zakat institutions, or to adopt economic programs of successful zakat institutions.

In general, economic development assistance and entrepreneurship programs for productive zakat distribution can be summarized into several categories, which are the category of capital and equipment assistance, short-term courses, training, skills and mentoring. Most of the aid and economic programs at the zakat institutions in Malaysia are managed by the zakat distribution section of the institution in the form of corporations, subsidiaries, the State Islamic Religious Council and the Baitulmal Fund. The status of these distributions management may have different effects in terms of power and efficiency as well as the effectiveness of the zakat institution in delivering its vision and mission to the target.

Capital assistance and equipment are provided to those who are already involved in the business, but lack of capital to run, grow and complete their business. Examples of those involved in the baking, workshops, hairdressers, retailers, fishermen, livestock, sewing, food stalls, businesses and other economic activities. All of them selected according to the informants are asnaf who are productive and ambitious in the business nature and pursuit to enhance their efforts as well as physical ability. Most zakat institutions have the goal of these asnaf to escape from the status of poor and needy beneficiaries.

For Asnaf and their children who are interested in participating in the business but have never been involved in the business, some zakat institutions make selections based on certain criteria and provide appropriate courses to the extent that these children can be given help. They are then monitored by their mentors appointed in their field of study. Once they have getting their confidence to do their work, then the zakat management institutions assist such as revolving capital, equipment, building rentals, providing buildings and business sites (marketing - asnaf markets) based on their business needs.

In addition to capital and equipment assistance, participants are presented with a short 2 to 3-day short course aimed at providing insight into the basics of business, manufacturing and service to Asnaf. Basic business courses such as how to carry out account books, stockpiling, packaging, branding and marketing. This short-term course is held at the zakat institution training center owned by state zakat management centers or outsourced by zakat institutions that do not have training centers. Manufacturing courses are held in the areas of frozen foods, handicrafts, food and catering. For service activities such as sewing courses, cooking courses, traditional courses such as massage and midwifery related. Many of these courses are held at state zakat training centers at their own buildings. For example at LZNK, at LZSB (Asnaf Ulu Yam Training Center), Penang Zakat (ZPP), MAIJ and MAIWP. However, institutions that do not have training centers, they will outsource through the State Islamic Religious Council, Baitulmal State and in cooperation with certain agencies. Generally, educators will be recruited from government agencies such as KEMAS (Community Development), MARA, 
Community College and the private sector as well as successful ex-asnaf in collaboration with the zakat management centers.

For economic assistance and programs through skills training, it is intended to give the beneficiaries skills to equip themselves in the field of employment aimed at securing jobrelated to industries by earning a high income or engaging in business-related skills. This program is usually completed in collaboration with government and private agencies that have Memorandum of Agreement (MOA) with zakat management institutions. This implementation requires a considerable allocation as done by TERAJU Sdn Bhd (LZS) with SIRIM (welding); Naza Academy (automotive); Construction Academy of Malaysia - ABM (heavy machinery) and Construction Industry Development Board - CIDB (plastering). The implementation of this agreement is not only started by providing training to the participants, but also by employing the participants. Likewise, skills training programs conducted under the management of MAIPK with ABM; SekataRakyat and UEM Bhd Group and LZNK with $\mathrm{ABM}$ and $\mathrm{CIDB}$.

The most important aid and economic programs, as well as initiatives involved with external and private agencies, are in the form of skills training for mentoring programs by providing more than 6 months of training especially to aspire the asnaf children in seeking skills by obtaining certificates that qualify the participants in getting jobs. For example, the parties involved are Kedah Industrial Skills and Management Development Centre (KISMEC) with LZNK. Among the private parties involved are ABM, Sime Darby (Automotive course), UEM Bhd Group, SekataRakyat, Aviation College, TWI Technology, Azmida Technical College, Naza Academy (Automotive course), Think Big Resources Sdn Bhd, Pearl Technology Center Sdn Bhd, IT Gets Solution (3D Animation course), Moca Resources (Oil \& Gas, Scarfolding), Mecatronic (Automotive), AutoPrima College (Automotive). There are also aspiring participants who have advanced intermediate and diploma skills based on the success of the course.

In addition to the assistance of economic programs and entrepreneurship, there are also joint programs with other zakat institutions, such as through cooperation with state zakat institutions, for example, the 2012 project at Asnaf Batu Berangkuk Village Park, Chuping in Perlis between LZS and MAIPs in developing asnaf economy in chili production. The Asnaf placement in collaboration between LZS and MAIK (Shah Alam Village, Pasir Putih), MAIDAM (Kampung Banggol, Kuala Terengganu) and at MUIP Pahang (Bukit Kenau).

In implementing these economic assistance and entrepreneurship programs, zakat institutions should have a standard mechanism, usually using the Standard Operating Procedure (SOP). This is because the SOP can assist implementers clearly and easily to execute economic and entrepreneurship assistance and programs. Almost all state zakat institutions have their own SOPs, except LZNK and MAIPs as these divisions are newly established after the establishment of a zakat corporation in Kedah and Asnaf Transformation Academic in Perlis and they are still under construction. There are zakat management institutions that offer courses, training and skills through the online portal of zakat management centers. The zakat management centers include MAIJ, LZS, MAIPk, MAIWP and MAINS. The target group is mostly children of asnaf as well as the poor and needy, some of those who are mualaf and fisabiliillah ${ }^{1}$.

${ }^{1}$ All zakat management centers favor the poor and needy except for MAIPk, MAINS and TBS which also provide economic and entrepreneurial assistance to the needy but few in number. Only zakat management centers such as LZS, MAINS and PZS-MUIS provide assistance to asnaf fisabilillah. 
There are three types of SOPs, the first of which is for those who are already involved with businesses and entrepreneurs and need attention and assistance in terms of capital, equipment and building sites. In the category of business owners and entrepreneurs, they are given business courses such as accounting, communications, productions, management and marketing after having their business capabilities inspected, they can grow through their talent and passion. The second is for the target group that does not have a business foundation and the entrepreneurs are mostly children. Those selected for the course will be handed over to TERAS Sdn Bhd to assist them with the necessary aspects of running their efforts and business. They are considered successful if their business has achieved the set of Key Performance Indicators (KPIs), which in turn have boosted their business income and not only outperformed those who received (asnaf) assistance. At this stage those selected will continue with the print program to further the business with additional assistance or the LZS will seek funding from external financing agencies such as the National Entrepreneur Group Economic Fund (Tekun Nasional), Amanah Ikhtiar Malaysia (AIM), People's Trust Council (MARA) and more. They are given a specific period to eliminate the business from monitoring after fulfilling the specified KPI. However, monitoring the spiritual aspects of becoming a zakat payer is a goal that should be used as a benchmark, not just out of the poverty of the poor and needy.

The third SOP is more to the selection of asnaf to receive skills training that takes over 6 months through the cooperation of the Malaysia External Trade Development Corporation (MATRADE), the Construction Industry Development Board of Malaysia (CIDB), Community College, Terengganu Skills Development Center (TesDec), Ria Academy College and higher institutions (UUM, UniSHAMS and UiTM), Kedah Industrial Skills and Management Development Centre (KISMEC). Among the private parties involved are ABM, Sime Darby (Automotive), UEM Berhad Group, SekataRakyat, Aviation College, TWI Technology, Azmida Technical College, Naza Academy (Automotive course), Fansuria Sdn Bhd, Think Big Resources Sdn Bhd, Pearl Technology Center Sdn Bhd, IT Gets Solution (3D Animation course), Moca Resources (Oil \& Gas skills course, Scarfolding), Mecatronic (Automotive course), AutoPrima College (Automotive course), Auto Prima College, Mangkuktingkat.com. The collaboration provided by the government and private agencies is more in the form of training and skills as well as mentoring and supervising.

The recipients of economic assistance programs that receive the most assistance are the poor and the needy asnaf. There are very little economic assistance and programs available to mualaf (zakat institutions such as PZS-MUIS, LZS and MAINS) and fisabiliillah (zakat institutions such as TBS, MAIPk and MAINS) as well as the disabled people (OKU).

In addition, this allocation for aids, economic programs and entrepreneurs is very small compared to the distribution of zakat overall, which is less than 2 percent of the total. Suppose LZS has allocated the highest budget of RM 7,000,000.00 and the lowest is PZS-MUIS Sabah with a total of RM 0.75 million. The average allocation for this economic development is RM1.5 million (LZNK, MAIJ, MAIM). The second and third with the highest allocation are MAIDAM and MAIPk of RM3 million and RM2.55 million respectively. For the MAIPk zakat institution, although the amount of its revenue collection is less than the LZS in Selangor and Wilayah, its economic development program is leading.

There is no provision for minimum capital assistance in all zakat institutions. Capital assistance depends on the urgent need of good participants in the form of round capital, equipment and commercial building rentals. However, there are zakat management centers that set maximum assistance such as LZS which can reach up to RM50,000.00. This is based on the zakat institution's confidence in the business venture as it has achieved the set KPI 
(after taking basic courses, advanced courses and getting support from mentors). The LZNK also provides average equipment assistance of RM5,000.00 and a maximum of RM7,000.00 for asnaf individuals. MAIWP also provided maximum capital assistance of up to RM35,000.00 to buy a vehicle for taxi service.

However, recipients of these aids and programs are sometimes frustrated by some of the problematic attitudes among asnaf who possessed sub-cultures such as lack of selfencouragement, not pro-active, lack of initiative, not self-reliance, and other negative attitudes. All of the zakat centers in Malaysia face this problem as the hindrance to the efforts of the zakat institutions. Besides, the institution also has less staff to implement assistance and programs to succeed especially the zakat institution under MAIN management.

\section{Summary}

There are generally three types of economic approaches adopted by zakat institutions in the states of Malaysia, which are their own economic approaches, cooperation between one zakat institution and another, the latter economic approach is cooperation between zakat institutions and external organizations including government departments and private agencies. From the philosophical point of view, almost all zakat institutions in Malaysia adopt the philosophy of giving fishing rod rather than giving fish to the asnaf. Giving the fishing rod is continued with efforts on how to use the fishing rod because if the rods provided cannot be used, it will not increase the revenue. However, the fishing rod provided and training on how to use it is not enough. It is as well crucial to know where most fishes are and which strategies could result in getting more fish.

The formulation of economic and entrepreneurial programs is aimed at enhancing the productivity, effort and business of selected poor and needy asnaf, mualaf and fisabiliillah. The types of economic assistance and programs provided to selected people include capital and equipment assistance categories, short term courses, training and skills as well as mentoring. Economic assistance and these economic and entrepreneurial programs are far less than aids and subsidies (including basic needs such as food, housing, health and education).

There are economic and entrepreneurial programs as well as initiatives undertaken by institutions only to the extent that they can only get help and programs without further assistance, which is to monitor the results successfully, such as those at MAIKs and TBM Sarawak. Some zakat institutions provide these aids and economic programs until they feel that their participants have fulfilled their KPI. Besides, this successful venture is furthered to develop their efforts, business and skills by helping to raise capital and training from funding agencies such as MARA, Tekun and Government Link Company (GLC) as implemented by LSZ, MAIPk, MAINS and MAIM.

The downside to implementing this economic approach is that the human resources involved in the zakat institution are very small especially the zakat institutions at MAIN. In addition, human resources involved lack the skills and expertise in implementing economic and entrepreneurial assistance and programs and have to involve external and private agencies in working together to implement them. In addition to the people who are involved, they also have sub-cultures such as less motivated, shy and have a sense of inferiority to be more proactive.

There must be positive steps, including the need for more economic and entrepreneurial funds, the right method of selecting the right people (for example, the ability and accuracy of the field involved), the cultivation of positive traits (motivation, diligence and attentiveness), providing more demanded courses in the job market, further enhance product marketing and 
skills development, conduct smart monitoring and collaboration with government and private sector agencies with skills and training. It is hoped that the above steps will help the zakat institution to implement economic and entrepreneurial assistance and programs better and more effectively.

\section{References}

[1] A. Ab Rahman, M. Y. Ali Basah, M. N. Nooh, M. F. A.A., and M. . Abu Bakar, "Urus Tadbir Ekonomi yang Adil: Ke Arah Ekonomi Berpendapatan Tinggi," in Prosiding Persidangan Kebangsaan Ekonomi Malaysia ke 9 (PERKIM). 17-19 Oktober 2014, 2014, pp. 191-198.

[2] Z. Bahari, "Transformasi Fakir Miskin Daripada Penerima Zakat Saradiri kepada Penerima Produktif," in Transformasi Zakat: Daripada Zakat Saradiri Kepada Zakat Produktif, Pulau Pinang, Malaysia: Pusat Urus Zakat, MAINPP \& Pusat Kajian Pengurusan Pembangunan Islam (ISDEV),Universiti Sains Malaysia, 2011, pp. 331364.

[3] M. R. Jalil, R. A. Mahad, H. Wahid, and S. Ahmad, "Strategi Pembangunan asnaf fakir dan miskin melalui penjanaan modal bantuan modal zakat," in Prosiding Seminar Zakat Peringkat Kebangsaan. Jabatan Syariah dan Ekonomi, Akademi Pengajian Islam, Universiti Malaysia, Kuala Lumpur, 2015.

[4] Zakat Report, "Satu Sumber Maklumat Zakat di Malaysia.” Kuala Lumpur, Malaysia, pp. 80-94, 2017.

[5] M. A. A. Muin and S. Abdullah, "Peranan Usahawan Sosial Berjaya Dalam Meningkatkan Dana Zakat di Malaysia: Kesan Pembangunan Ekonomi Ummah,” in Buku Menelusuri Isu-isu Kontemporari Zakat, 2016, pp. 275-288.

[6] A. Ab Rahman and N. Ismail, "Analisis SKIM Agihan Zakat Kepada Mualaf Berasaskan Maqasid Syari'ah di Majlis Agama Islam Negeri Sembilan,” in Buku Menelusuri Isu-isu Kontemporari Zakat, Pusat Pungutan Zakat (PPZ), 2016, pp. 251262.

[7] F. A. Yaacob, "Usahawan asnaf di Lembaga Zakat Selangor," Pusat Kajian Pengurusan Pembangunan Islam. Universiti Sains Malaysia, 2014.

[8] A. Nasrun and A. S. Azman, "Strategi Pembangunan Asnaf Fakir dan Miskin Melalui Penjanaan Modal Bantuan Modal Zakat," in E-Prosiding Seminar Zakat Peringkat Kebangsaan 2015, 2015, pp. 36-49.

[9] R. Firdaus and M. M. Nur, "Model Pemberdayaan Ekonomi Berbasis Zakat Produktif dalam Meningkatkan Pendapatan Masyarakat di Provinsi Aceh," in Proceeding of International Conference of Empowering Islamic Civilizatio, 2017, pp. 7-8.

[10] N. I. M. Adnan, "Mikro Kredit Daripada Dana Zakat: Satu Sorotan," in Satu Sorotan dalam Menelusuri Isu-isu Kontemprorari Zakat, Malaysia: Pusat Pungutan Zakat (PPZ), 2017, pp. 239-250.

[11] P. Ibrahim, "Mengoptimakan Pembiayaan Dana Zakat Untuk Golongan Miskin dan Memerlukan," in Transformasi Zakat: Daripada Zakat Saradiri Kepada Zakat Produktif, Pusat Urus Zakat, MAINPP \& Pusat Kajian Pengurusan Pembangunan Islam (ISDEV), 2011, pp. 365-398. 